\title{
KINETIC PARAMETER ANALYSIS OF MYELOPEROXIDASE IN THE PRESENCE OF SOME COSUSBTRATES IN SALIVA OF NEWBORN AT RISK OF SEPSIS
}

\author{
ARI YUNANTO ${ }^{1}$, EDI HARTOYO ${ }^{1}$, ISKANDAR THALIB ${ }^{1 *}$, NIARSARI ANUGRAHING PUTRI ${ }^{1}$, EKO SUHARTONO ${ }^{2}$ \\ ${ }^{1}$ Department of Child Health, Faculty of Medicine, Lambung Mangkurat University, Banjarmasin, Indonesia. ${ }^{2}$ Department of Medical \\ Chemistry/Biochemistry, Faculty of Medicine, Lambung Mangkurat University, Banjarbaru, Indonesia. Email: iskandarthalib@gmail.com
}

Received: 21 November 2019, Revised and Accepted: 24 January 2020

\section{ABSTRACT}

Objective: During infection like sepsis, myeloperoxidase (MPO) enzyme will be generated from the neutrophil. This enzyme will catalyze the oxidation of halide or pseudohalide ( $\mathrm{Cl}, \mathrm{I}, \mathrm{SCN}$, and $\mathrm{Br}$ ) using hydrogen peroxide $\left(\mathrm{H}_{2} \mathrm{O}_{2}\right)$. However, the mechanism by which oxidation of these several cosubstrates in neonatal sepsis is unknown. Here, we have compared the kinetic parameter of MPO in saliva of newborn at risk of sepsis with or without the presence of these several cosubstrates.

Methods: In this experiment, saliva samples were taken from newborn in health $(\mathrm{n}=20)$ and risk of sepsis $(\mathrm{n}=20)$. Saliva samples from each group then homogenized and divided into four groups. Group 1 served as control which contains saliva $+\mathrm{H}_{2} \mathrm{O}_{2}$; Group 2 contains saliva $+\mathrm{H}_{2} \mathrm{O}_{2}+\mathrm{Cl}^{-}$; $\mathrm{Group} 3$ contains saliva $+\mathrm{H}_{2} \mathrm{O}_{2}+\mathrm{I}^{-}$; and Group 4 contains saliva $+\mathrm{H}_{2} \mathrm{O}_{2}+\mathrm{SCN}^{-}$. After $1 \mathrm{~h}$ incubation, the kinetic parameters (Km and Vmax) were analyzed.

Results: The result shows that in sepsis condition, compared without the presence of some cosubstrates, it seems the addition of some cosubstrate will increase the affinity between $\mathrm{MPO}, \mathrm{H}_{2} \mathrm{O}_{2}$, and the cosubstrate. Between these three cosubstrates, it seems in sepsis condition $\mathrm{MPO}$ will oxidize $\mathrm{Cl}^{-}$.

Conclusion: In sepsis condition, MPO works by a common mechanism, that is, oxidizing $\mathrm{Cl}^{-}$to hypochlorous acid than another cosubstrate.

Keywords: Myeloperoxidase, Neonatal Sepsis, Saliva

(C) 2021 The Authors. Published by Innovare Academic Sciences Pvt Ltd. This is an open access article under the CC BY license (http://creativecommons. org/ licenses/by/4.0/) DOI: http://dx.doi.org/10.22159/ijap.2021.v13s1.Y0072. Journal homepage: https://innovareacademics.in/journals/index.php/ijap

\section{INTRODUCTION}

Neonatal sepsis (NS) is still a problem in the worldwide because it is one of the leading causes of neonatal death. It is estimated that more than $40 \%$ death of children under-5 years old occur in neonates, and each year there are 3.1 million neonates who die in the world [1]. The death of the neonate is mostly caused by NS. NS is responsible for $30-50 \%$ of all total neonatal deaths, especially in developing countries [2].

NS is a clinical syndrome which is characterized by a hemodynamic, respiratory, and metabolic disturbance process due to systemic infection that can trigger an abnormal systemic inflammatory response syndrome in infants [3,4]. The signs and symptoms of NS are varied and not specific. This causes the diagnosis of NS to be difficult. Until now, only blood culture can be a definitive diagnosis for NS, but as it is known, blood culture takes a long time and is quite expensive. The difficulties of this diagnosis make some of clinicians used "Suspected sepsis" to diagnoses NS before the blood culture results [5].

The pathomechanism of NS is still unclear, but several studies have suggested that myeloperoxidase (MPO) enzyme was involved in these pathomechanism. Our previous result study shows that the level of MPO was significantly higher in saliva of newborn with risk of sepsis compared to healthy newborn [6]. The MPO level elevation in NS is thought to be caused by an immune and inflammatory response during NS. This response was important in these time, because it plays an important role in killing invading parasites and pathogens [5].

MPO is a heme-containing enzyme which is produced by neutrophils during phagocytosis. MPO plays an important role in killing pathogens through the formation of reactive oxidants which acts as an antimicrobial $[7,8]$. Furthermore, because MPO is one of the peroxidases family enzyme, it also can act as a catalyst of hydrogen peroxide $\left(\mathrm{H}_{2} \mathrm{O}_{2}\right)$ removal, depending on the conditions under which it operates. If the MPO plays a role in the defense mechanism against the pathogen, MPO will use $\mathrm{H}_{2} \mathrm{O}_{2}$ and halide (iodide, bromide, chloride, and thiocyanate; $\mathrm{I}, \mathrm{Br}, \mathrm{Cl}$, and $\mathrm{SCN}$ ) to produce pseudo-halide such as hypoiodous acid (HOI), hypobromous acid, hypochlorous acid ( $\mathrm{HOCl}$ ), and hypothiocyanite acid (HOSCN). Conversely, if the MPO plays a role for $\mathrm{H}_{2} \mathrm{O}_{2}$ removal, then the MPO will catalyze the change of $\mathrm{H}_{2} \mathrm{O}_{2}$ into water $\left(\mathrm{H}_{2} \mathrm{O}\right)$ and oxygen $\left(\mathrm{O}_{2}\right)[9,10]$.

Study of kinetics parameters of an enzyme is important to explain the work mechanism of the enzyme. From this point of view, it is important to know the kinetic parameters of the MPO in NS considering that many reactions catalyzed by MPO. Due to important role of MPO in NS, the work mechanism in these diseases has attracted much attention. In this regard and for better understanding of the possible mechanisms of MPO with the presence of some cosubstrates (I, Cl, and SCN) in NS, changes in the kinetic parameters of MPO on interaction with those cosubstrates were studied.

\section{MATERIALS AND METHODS}

Participants

This was a prospective study conducted from December 2016 to June 2017. Ethical approval was obtained from the Ethics Commission of the Faculty of Medicine, Lambung Mangkurat University, Banjarmasin, South Kalimantan, Indonesia (approval number: 2010019). Written informed consent was obtained from all guardians on behalf of the newborn participants involved in the study. Patients who were participated in this study are newborn with risk of $\mathrm{SN}(\mathrm{n}=15)$ based on The American Congress of Obstetricians and Gynaecologist guidelines criteria for NS. Patients who were participated must at least have 1 major criterion or 2 minor criteria according to these criteria. Healthy newborns $(\mathrm{n}=15)$ were included as controls. 
Saliva samples collection

The patient's salivary sample is taken from the mouth of the newborn at the time of clearing the oral cavity using a sterile polypropylene transfer pipettes. The saliva was taken by giving $0.9 \% \mathrm{NaCl}$ solution slowly using the transfer pipettes at the bottom of the patient's tongue and then the mixture of the saliva and $\mathrm{NaCl}$ was taken again as much as $5 \mathrm{ml}$. Samples were transported on ice to the laboratory where they were centrifuged at $176 \mathrm{~g}$ for $5 \mathrm{~min}$ and the supernatants stored until further analysis

\section{Experimental section}

Samples were divided into four groups from each condition (health and risk of sepsis). Group 1 contained healthy/sepsis newborn saliva $+\mathrm{H}_{2} \mathrm{O}_{2}$ and SN saliva $+\mathrm{H}_{2} \mathrm{O}_{2}$, respectively. Group 2 contained healthy/sepsis newborn saliva $+\mathrm{H}_{2} \mathrm{O}_{2}+0.1 \mathrm{M}$ of $\mathrm{NaCl}$ and $\mathrm{SN}$ saliva $+\mathrm{H}_{2} \mathrm{O}_{2}+0.1 \mathrm{M}$ of $\mathrm{NaCl}$, respectively. Group 3 contained healthy/sepsis newborn saliva + $\mathrm{H}_{2} \mathrm{O}_{2}+0.1 \mathrm{M}$ of $\mathrm{KI}$ and SN saliva $+\mathrm{H}_{2} \mathrm{O}_{2}+0.1 \mathrm{M}$ of KI, respectively. Group 4 contained healthy newborn saliva $+\mathrm{H}_{2} \mathrm{O}_{2}+0.1 \mathrm{M}$ of SCN and SN saliva $+\mathrm{H}_{2} \mathrm{O}_{2}+0.1 \mathrm{M}$ of SCN, respectively.

\section{MPO activity analysis}

MPO activity was measured by spectrophotometric using o-dianisidine (Sigma-Aldrich) and $\mathrm{H}_{2} \mathrm{O}_{2}$. In the presence of $\mathrm{H}_{2} \mathrm{O}_{2}$ as oxidizing agents, MPO catalyzes the oxidation of o-dianisidine yielding a brown-colored product, oxidized o-dianisidine, with a maximum absorbance at $470 \mathrm{~nm}$. One unit (U) of MPO activity was defined degrading $1 \mu \mathrm{mol}$ of $\mathrm{H}_{2} \mathrm{O}_{2}$ per minute at $25^{\circ} \mathrm{C}[11]$.

\section{MPO kinetic parameters analysis}

Kinetic parameters were determined using five different concentrations of the substrate, $\mathrm{H}_{2} \mathrm{O}_{2}$. Substrate concentrations are $6.25,12.5,25$, and $50 \mathrm{mM}$ of $\mathrm{H}_{2} \mathrm{O}_{2}$. The kinetic parameters, Vmax, and $\mathrm{Km}$, were determined using the Lineweaver-Burk version of the Michaelis-Menten equation, as follows:

$$
\frac{1}{V}=\frac{\mathrm{km}}{V \max } \backsim \frac{1}{[\mathrm{~S}]}+\frac{1}{V \max }
$$

$\mathrm{V}$ is the reaction velocity. Vmax is the maximum reaction velocity. $\mathrm{Km}$ is the Michaelis constant (substrate concentration at half-maximal reaction velocity) and [S] is the substrate concentration [5].

\section{RESULTS AND DISCUSSION}

In this study, the kinetic parameters of MPO with and without the presence of some cosubstrate in saliva of newborn at risk of sepsis were investigated. Kinetic parameters of salivary MPO were determined using Lineweaver-Burke plot. From this plot, a Michaelis-Menten equation used to determine the Km and Vmax values for both groups with and without the presence of different cosubstrates (Figs. 1 and 2 and Table 1). From Fig. 1 and Table 1, the Vmax of the salivary MPO in healthy newborns group ranges from 0.035 to $0.041 \mathrm{~s} 1$, while the Vmax values in sepsis

Table 1: Kinetic parameters ( $\mathrm{Km}$ and $\mathrm{Vmax}$ ) and coefficient correlation for salivary MPO in different groups in normal and sepsis newborn. Group 1: Saliva and $\mathrm{H}_{2} \mathrm{O}_{2}$; Group 2: Saliva, $\mathrm{H}_{2} \mathrm{O}_{2}$, and $\mathrm{NaCl}$; Group 3: Saliva, $\mathrm{H}_{2} \mathrm{O}_{2}$, and $\mathrm{KI}$; and Group 4: Saliva,

$$
\mathrm{H}_{2} \mathrm{O}_{2} \text {, and SCN }
$$

\begin{tabular}{lllll}
\hline \multirow{2}{*}{ Condition } & Group & \multicolumn{2}{l}{ Parameters } \\
\cline { 3 - 5 } & & Km & Vmax & r \\
\hline Normal & 1 & 0.235 & 0.035 & 0.981 \\
& 2 & 0.070 & 0.037 & 0.960 \\
& 3 & 0.216 & 0.039 & 0.917 \\
Sepsis & 4 & 0.080 & 0.041 & 0.984 \\
& 1 & 0.338 & 0.035 & 0.951 \\
& 2 & 0.064 & 0.039 & 0.907 \\
& 3 & 0.080 & 0.039 & 0.941 \\
& 4 & 0.148 & 0.043 & 0.981 \\
\hline
\end{tabular}

MPO: Myeloperoxidase, $\mathrm{H}_{2} \mathrm{O}_{2}$ : Hydrogen peroxide newborn group are within the range of $0.035-0.043 \mathrm{~s} 1$. Furthermore, from Fig. 2 and Table 1, the Km values in healthy newborn group are within the range of $0.070-0.0 .235$, while the Km values in sepsis newborn group are within the range of 0.064-0.338. The highest Vmax values was found in Group 3 of healthy newborn group, while in the sepsis newborn group was found in Group 4. However, the Vmax values were found not much different between each group. The highest $\mathrm{Km}$ values were found Group 1 of both healthy and sepsis newborn, while the lowest Km values were found in Group 2 of healthy newborn and Group 3 of sepsis newborn.

To the best of our knowledge, the Vmax value illustrates the ability of an enzyme to catalyze the substrate, and the Km value illustrates enzyme and substrate affinity. From this point of view, the higher value of Vmax reflects a better enzyme's ability to catalyze its substrate. In contrast to the Vmax value, a higher Km value reflects the low affinity of the enzyme against its substrate. This means, the reaction will shift to the left. The shift in the reaction results in a decrease in the product level [12-14].

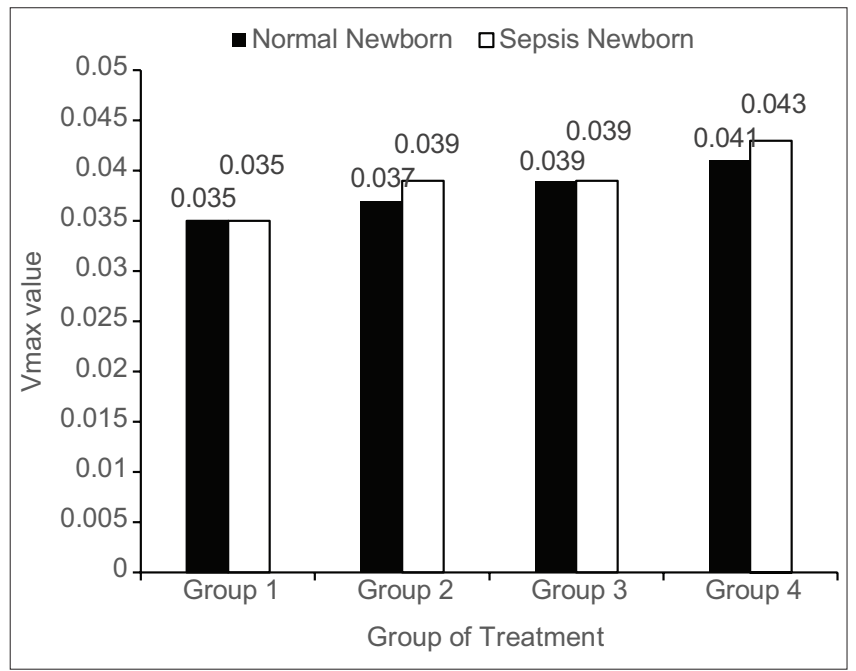

Fig. 1: The Vmax value comparison of salivary myeloperoxidase between groups in normal and sepsis conditions. Group 1 contains saliva and hydrogen peroxide $\left(\mathrm{H}_{2} \mathrm{O}_{2}\right)$; Group 2 contains saliva, $\mathrm{H}_{2} \mathrm{O}_{2}$, and $\mathrm{NaCl}$; Group 3 contains saliva, $\mathrm{H}_{2} \mathrm{O}_{2}$, and $\mathrm{KI}$; and Group 4 contains saliva, $\mathrm{H}_{2} \mathrm{O}_{2}$, and $\mathrm{SCN}$

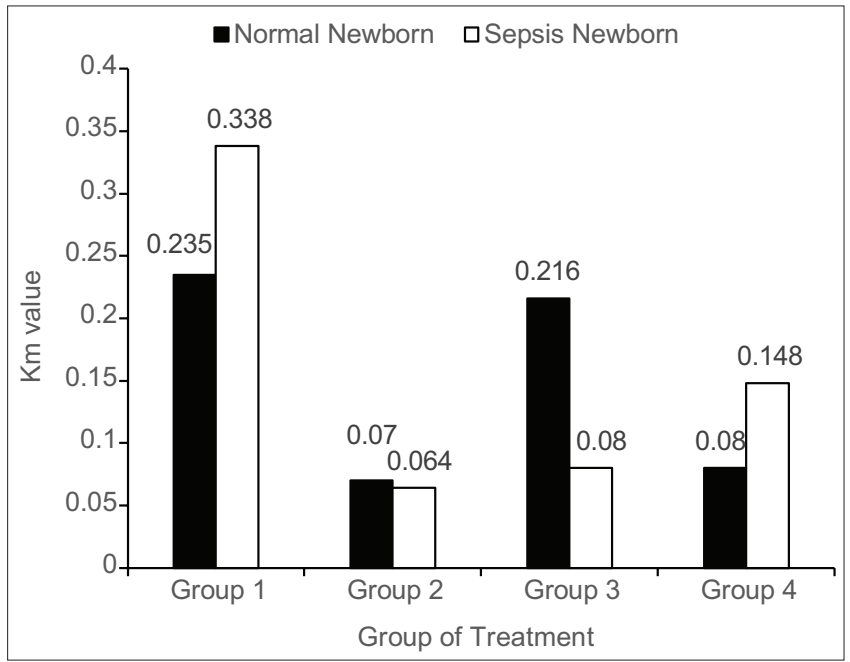

Fig. 2: The Km value comparison of salivary myeloperoxidase between groups in normal and sepsis conditions. Group 1 contains saliva and hydrogen peroxide $\left(\mathrm{H}_{2} \mathrm{O}_{2}\right)$; Group 2 contains saliva, $\mathrm{H}_{2} \mathrm{O}_{2}$, and $\mathrm{NaCl}$; Group 3 contains saliva, $\mathrm{H}_{2} \mathrm{O}_{2}$, and $\mathrm{KI}$; and Group 4 contains saliva, $\mathrm{H}_{2} \mathrm{O}_{2}$, and $\mathrm{SCN}$ 
Results of this present study indicated that the addition of some cosubstrate does not affect the catalytic ability of MPO both in normal or sepsis condition. However, different things happen at Km value. According to our results, it seems sepsis condition decreases the affinity between MPO and $\mathrm{H}_{2} \mathrm{O}_{2}$. It can be seen from the higher value of $\mathrm{Km}$ in sepsis group compare to normal group without the addition of some cosubstrate. Interesting results can be found at the value of $\mathrm{Km}$ after some cosubstrate additions. In sepsis condition, the additions of some cosubstrate seem to increase the affinity between MPO and the substrate and cosubstrate. The strongest affinity of MPO was found in chloride addition.

The increasing of affinity of MPO in sepsis condition means the binding between MPO and $\mathrm{H}_{2} \mathrm{O}_{2}$ might be stronger by the presence of those cosubstrates. This condition will increase the concentration of $\mathrm{HOCl}$, hypothiocyanite acid, and HOI as a product. Between these three products, it seems MPO rather to oxidize chloride than the two others. It can be seen from the lowest $\mathrm{Km}$ value in chloride group than another group. To the best of our knowledge, as far as we are aware, this the first study of MPO kinetic parameter analysis in saliva of newborn at risk of sepsis. However, several previous studies only stated that there was an increasing level or activity of MPO in saliva and plasma of newborn at risk of sepsis [6,14-16].

It is well known that MPO is a heme enzyme that use $\mathrm{H}_{2} \mathrm{O}_{2}$ to oxidize some cosubstrate including $\mathrm{Cl}^{-}, \mathrm{I}^{-}, \mathrm{Br}^{-}$, and $\mathrm{SCN}^{-}$. The activity of MPO to oxidize those cosubstrates is relatively non-specific. However, between those cosubstrates, $\mathrm{Cl}^{-}$was accepted as a physiological cosubstrate because a higher concentration in plasma than another cosubstrate. This is in line with our results study. The result of this present study indicated that with the present of $\mathrm{Cl}^{-}, \mathrm{I}^{-}$, and $\mathrm{SCN}^{-}, \mathrm{MPO}$ rather to oxidize $\mathrm{Cl}^{-}$than $\mathrm{I}^{-}$and $\mathrm{SCN}^{-}$[9]. The production of $\mathrm{HOCl}, \mathrm{HOI}$, and HOSCN by MPO is essential in host defense mechanisms. These productions deploy bactericidal activity on the bacteria ingested in the phagosome [17].

\section{CONCLUSION}

From this present study, it can be concluded that the addition of some cosubstrates in sepsis condition will lead to decrease the $\mathrm{Km}$ value of MPO, but not Vmax. It seems the presence of some cosubstrates in sepsis condition will activated MPO to catalyze the oxidation of $\mathrm{Cl}^{-}$, $\mathrm{I}^{-}$, and $\mathrm{SCN}^{-}$, which is important to killing the bacteria during sepsis condition. The result also shows that in sepsis condition, MPO will oxidize $\mathrm{Cl}^{-}$to form $\mathrm{HOCl}$ than another cosubstrate.

\section{ACKNOWLEDGMENT}

The authors would like to thank all team at Ulin General Hospital who help to gathered data.

\section{REFERENCES}

1. El-Din EM, El-Sokkary MM, Bassiouny MR, Hassan R. Epidemiology of neonatal sepsis and implicated pathogens: A study from Egypt. Biomed Res Int 2015;2015:1-11.

2. Verma P, Berwal PK, Nagaraj N, Swami S, Jivaji P, Narayan S. Neonatal sepsis: Epidemiology, clinical spectrum, recent antimicrobial agents and their antibiotic susceptibility pattern. Int J Contemp Pediatr 2015;2:176-80.

3. Dessi A, Pravettoni C, Ottonello G, Birocchi F, Cioglia F, Fanos V. Neonatal sepsis. J Pediatr Neonatal Individ Med 2014;3:e030273.

4. Joshi G, Kumar A. A review on early and late neonatal sepsis: An update. J Pharm Res 2017;11:609-16.

5. Yunanto A, Thalib I, Suhartono E. In-vitro effects of some antibiotic drugs on saliva thiocyanate and oxidation protein products levels on newborn at risk of sepsis. Int J Pharm Clin Res 2016;8:86-9.

6. Yunanto A, Andayani P, Triyawanti, Suhartono E, Widodo A. Neutrophil phagocytosis activity compared to myeloperoxidase, hydrogen peroxidase and lactoferrin levels in saliva of newborn baby with sepsis risk factors to detect early-onset neonatal sepsis. Int J Pharm Sci Invent 2013;2:18-22.

7. Teng N, Maghzal GJ, Talib J, Rashid I, Lau AK, Stocker R. The roles of myeloperoxidase in coronary artery disease and its potential implication in plaque rupture. Redox Rep 2017;22:51-73.

8. Tahboub YR, Abu-Soud HM. Steady-state study of inhibitory effect of nitrite on myeloperoxidase catalytic activity by hydrogen peroxide biosensor. Port Electrochim Acta 2010;28:27-38.

9. Davies MJ. Myeloperoxidase-derived oxidation: Mechanisms of biological damage and its prevention. J Clin Biochem Nutr 2011;48:8-19.

10. Klebanoff SJ. Myeloperoxidase: Friend or foe. J Leukoc Biol 2005;77:598-625.

11. Kania N, Thalib I, Suhartono E. Chlorinative index in liver toxicity induced by iron. Int J Pharm Clin Res 2016;8:1300-4.

12. Yunanto A, Gunawan P, Iskandar, Suhartono E. Effect of antibiotic applications on salivary amylase and catalase kinetic parameters on neonatal at risk of sepsis in vitro. Int $\mathrm{J}$ Toxicol Pharm Res 2015;7:269-73.

13. Marisa D, Rudito M, Zagita MG, Biworo A, Suhartono E. Hepatotoxicity effect of rifampicin and isoniazid via chlorinative stress pathway mechanism in-vitro. Int J Toxicol Pharm Res 2016;8:18-22.

14. El-Gammasy TM, Abushady NM, Hamza MT, Shaker R. Increase myeloperoxidase activity as an indicator of neutrophil-induced inflammation and sepsis in neonates. Egypt Pediatr Allergy Immunol 2015;13:15-20.

15. Nichols SJ, Hazen SL. Myeloperoxidase and cardiovascular disease. Arterioscler Thromb Vasc Biol 2005;25:1102-11.

16. Lau D, Mollnau H, Eiserich JP, Freeman BA, Daiber A, Gehling UM, et al. Myeloperoxidase mediates neutrophil activation by association with CD11b/CD18 integrins. Proc Natl Acad Sci U S A 2005;102:431-6.

17. Stark J, Varga Z, Ghidan A, Vajdovich P, Szombath D, Marczell I, et al. The effect of indomethacin, myeloperoxidase, and certain steroid hormones on bactericidal activity: An ex vivo and in vivo experimental study. Ann Clin Microbiol Antimicrob 2014;13:27. 